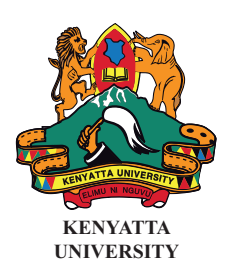

\title{
CHEMCHEMI
}

International Journal of Humanities and Social Sciences

Volume 11 Number 1, 2020

\section{THE CONTRIBUTION OF THE ANGLICAN CHURCH OF KENYA TO THE TRANSFORMATION OF KIRINYAGA DISTRICT, 1910-2010}

\author{
E. Akattu, M. A. J. Ndeda and E. Gimode
}

\begin{abstract}
Drawing on the theory of social capital, the initial attraction of Kirinyaga people to the Anglican Church of Kenya (ACK) mission centres were the schools, hospitals, demonstration gardens and artisan skills that imparted by missionaries. The ACK established Christian communities in Kirinyaga that became centres of early Christian converts and change. The Christian communities constituted "the germ of the missionary spirit." The 'new' Christians would take a great deal of pleasure in spreading the "germ" to many communities in Kirinyaga, 'infecting' the more susceptible of its members. Each Christian community endeavored to have a church, an elementary school, a hospital and a demonstration garden. This in itself was an extraordinary change. This study has presented evidence of Kirinyaga's cultural, socio-economic and political homogeneity as fundamental part of traditional life. European settlement in Kenya made oppression and injustice virtually inevitable and mission response to African issues ranged from land and labor to taxation and wages. The Anglican CMS almost exclusively provided such public services as schooling, healthcare and agriculture. This study also discussed regionalization of ACK CCS as a concept of community development focusing on CCSMKE serving the whole community in Kirinyaga, with priority on the most disadvantaged parts of the region, whether or not there are any Anglican congregations in that region. One of the discussions advanced in this study, is that the Anglican Church in Kirinyaga should have concern for Kirinyaga people as the concern of her social gospel. The study articulates a "theology of development" which argues that social gospel that is based on exploitation and oppression of Kirinyaga people cannot be genuine social gospel.
\end{abstract}

\section{Introduction}

Christian missionaries made significant contributions to Kenya's religious and cultural landscape. Strikingly parallel from the colonial administrators, it is the profound work of Christian missionaries that precipitated the introduction of a Western style of education and literacy into the mission territories by means of scripts and language use (Kalu, 2007, p. 212). The effort of the missionaries to translate the principal Christian literature, such as the Bible and catechism, into the vernaculars triggered the reduction of the vernaculars into writing and the gradual development of standard orthographies (Debrunner, 1967). Concisely put, the works of European missionaries were an oasis that poured a full tide of development in areas of architecture and structural design in Kenya. In equal breath, the same could be said of the introduction of Western culinary arts and kitchen ware (Kalu, 2007, p. 203). Particularly through their social mission, the missionaries enabled the introduction of Western style medicare. The institutions they set up, such as schools and hospitals, introduced Western institutional models and birthed a generation of new professionals such as teachers, medical doctors and nurses (Kalu, 2007). Thus the missionaries made lasting contributions to the religious and cultural landscape of Kenya.

The ACK's mission combines evangelism and development. Thus every diocese tries to integrate the two. The preaching of the "good news" by the CMS missionaries was always accompanied by setting up of churches, schools, health care facilities, youth vocational training centres, demonstration gardens, agricultural extension services, community sensitization, denunciation of harmful traditional practices, and life skills (ACK Embu, 2010, p. 21; TAABCO, 2008, p. 5). Mission facilities were centres of transforming people holistically. Out of these early efforts, many schools were established that have produced competent people, some of whom are key leaders in Kenya today. 
Besides education, the ACK was equally involved in the provision of healthcare. Today, most of the schools have been taken over by the government, but the ACK still has stakeholder interest as the sponsor of these institutions.

The regionalisation of the Anglican Church of Kenya (ACK) community development services saw the establishment of ACK Christian Community Services (CCS) which enabled the church fulfil its social outreach role. The concept of community development services as conceived in regionalization was that the focus of the ACK would be on serving the whole community, with priority on the most disadvantaged parts of the region, regardless of their affiliation (TAABCO, 2008). Some dioceses were already doing this, but they faced resistance from many pastors who were rigidly focused on the traditional parish approach. Although ACK is not the only church that participated in the social transformation of communities, it was picked because of the significance of its political involvement in colonial and post-colonial Kenya. The Anglican Church of England, for example, adhered to the social gospel, but also enjoyed 'established' status (Hastings, 1991, p. 2002). For instance the state consulted their views on African affairs; colonial officials often worshipped in their churches; and the Anglican Bishop opened the Legislative Council sessions with prayer. In Kenya, nearly the entire Kirinyaga was evangelized predominantly by the Anglican missionaries of the Church Missionary Society (CMS). The other churches were Seventh Day Adventists, Baptists, Pentecostals, Methodists, Presbyterians, Brethren, Roman Catholic and Independent churches among others.

This study examined the utilization of the social gospel by the ACK in the transformation of the rural communities in Kirinyaga. By 1910, there were a dozen Protestant missionary societies as well as Roman Catholics working in Kenya. Most had informal agreements not to preach in the other's territory and the colonial government, anxious to prevent denominational rivalry, formalized the situation by forbidding the building of a permanent missionstation within 10 miles of that of a different denomination. Four of the biggest missions joined to form the Alliance of Protestant Missionary societies - the Church Missionary Society, the Church of Scotland Mission, the Africa Inland Mission and the United Methodist Mission. The alliance was actually concerned with missionary activity in Central Kenya, the area occupied by Kirinyaga and her neighbours. Apart from these local considerations, the Protestant world was waking up to the scandal of its disunity. Given the nature of the distribution of foreign societies in Central Kenya, this study follows the activities of a denomination that was established in the early $20^{\text {th }}$ century and did a lot in Kirinyaga. Although the ACK is one of the earliest missionary churches in Kirinyaga, there is lack of detailed information on the utilization of the social gospel in the transformation of rural communities since the advent of the Anglican CMS.

Actions undertaken by mainline churches, including the ACK, Presbyterians and Catholics in Kirinyaga helped create political and social awareness. The ACK played significant civic and public roles particularly in civic education, monitoring and observing elections and in some cases even documenting the outright electoral malpractices and abuses of human rights, pushing for constitutional reforms in the early 1990s. The ACK remained engaged both in social and civic issues in Kirinyaga until the 2002 general elections that brought an end to Kenya African National Union (KANU)'s 39 years rule. Following the post-election violence in Kenya, the ACK and other churches were heavily involved in the Constitution review process until $4^{\text {th }}$ August, 2010 when Kenyans resolved to adopt a New Constitution. Philadelphia Retreat \& Conference Centre in Kirinyaga was involved in civic education with regard to the new Constitution. The centre organized a series of seminars to sensitize Kirinyaga people to make informed decision on the referendum day and submitted memoranda to different review organs. Therefore, Philadelphia centre in Kirinyaga contributed towards the acceptability of the new Constitution by majority of Kirinyaga voters (The Philadelphia Declaration Report, 2011).

\section{Literature Review}

Literature on the church in the transformation of rural communities and rural development has shown that the ACK and other mainline churches have been involved in transforming rural communities by applying the social gospel. Communities in Gichugu and Mutira mediated change in their individual and collective concerns on the eve of major European settlement in 1910 (Davison, 1996). Ambiguity marked the relation between white settlers and evangelists in Kirinyaga. The Church Missionary Society and the Church of Scotland Society, the two strongest British missionary societies in Kenya, adhered to a social gospel in addition to enjoying 'established' status (Lonsdale, 2002). ACK Missionaries favoured total Christian communities in areas where Africans made their own living in order to invent economic clients and tenants as potential converts (Lonsdale, 2002). The ACK missionaries exercised authority on matters of faith, but this trend underwent a paradigm shift when the Bible was translated into the indigenous Kirinyaga language (Gathogo, 2011a). Translation of the Bible into vernacular 
languages and teaching converts to read it for themselves was in itself revolutionary. ACK missions needed to create a new form of identity for converts so as to regulate their lives. This influenced their eating habits, living habits, social relations, economic concepts and, above all, the introduction of new religious beliefs (Nyaundi, 1993; Wilson, 1969). Converts were also expected to wear a Western style of clothing; to build square houses rather than round ones; to settle in a village round the church and school rather than scattered homesteads (Wilson, 1969). ACK activities in Kirinyaga brought social, political and cultural change, not only in the field of religious and moral conceptions, but also in the domain of technical capacities, habits of consumption, ways of living and hygiene (Barrett, 1971).

\section{Methodology}

\section{The Study Area}

Kirinyaga County has four administrative divisions namely; Ndia, Central, Gichugu and Mwea. The County borders Embu, Nyeri and Muranga'a Counties. The County has four constituencies namely; Ndia, Gichugu, Mwea and Kerugoya/Kutus. Ndia Constituency covers Ndia Divisions, Gichugu Constituency covers Gichugu Division and Mwea Constituency covers Mwea Division while Kerugoya/Kutus Constituency covers Central Division (County Council of Kirinyaga, 2012).

The Central Division is characterized by urban and per-urban settlements. The high population here could be attributed to the influx of people from the rural to the urban area where the county's headquarters are located for the purposes of conducting business and seeking employment. Mwea Division on the other hand has scattered homesteads and a high concentration of villages in the rice-growing area spotting large tracts of land for rice growing (Kirinyaga District Development Plan, 2002-2008). Gichugu and Ndia Divisions are characterized by scattered villages built on pieces of land that were allocated to the landless. An urban type of settlement is common in all divisions in the County. As a result, it was possible to collect data from ACK that were both in the villages and urban areas. Data analysis from such findings would easily be replicated throughout the entire County. Figure 1 shows the location of Kirinyaga county.

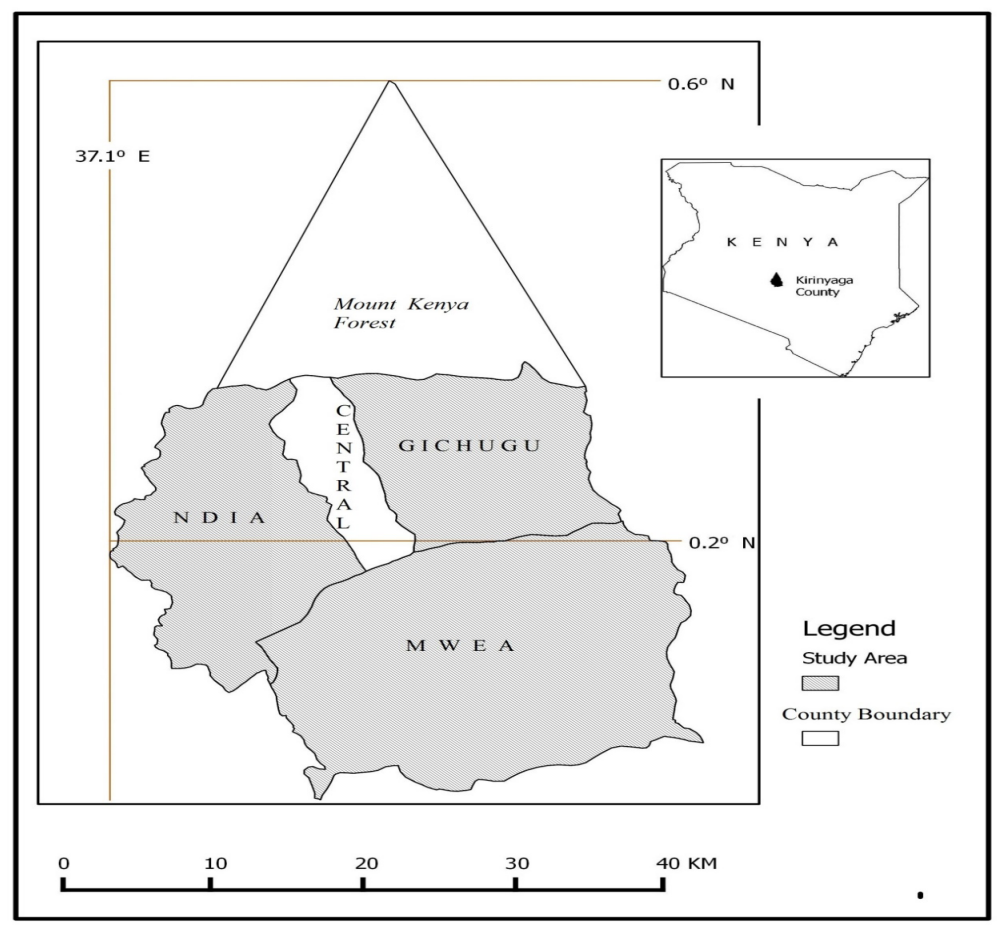

Source: Kirinyaga District Development Plan, 2008-2012 


\section{Research Design}

The study used both qualitative and quantitative research techniques because of the need for in depth description of historical events. Both descriptive and exploratory types of research were applied in this investigation. Purposive sampling and snowball techniques were used to identify various categories of key informants. A total of 100 respondents were interviewed. These were categorised into 5 groups, consisting of men and women in Kirinyaga who knew the history of the study area, past and current ACK staff, the clergy/bishops, prominent persons/ Government of Kenya (hereafter GoK) and CCSMKE staff in the locality by visiting the five ACK Archdeaconries namely; Mutira, Cathedral, Kiandangae, Kabare and Ngiriambuin Gichugu and Ndia divisions of Kirinyaga. Twenty respondents from each of the five ACK Archdeaconries were interviewed. The purpose here was to talk to a varied spectrum within the target population.

\section{Data Collection and Analysis Methods}

This investigation combined data collection methods such as archival research, oral interviews and observations. An extensive desk study on written documents was done on both primary and secondary sources of information. Archival data was cross-checked with oral testimonies to eliminate any bias since it was mostly written by colonial administrators who were often not knowledgeable on African situations.

Data processing and analysis involved establishing the chronology, coding, transcribing and translating into English some of the data collected in Gikuyu and Kiswahili languages. Archival and library data were subjected to document review analysis in tandem with other sources. The activities of the ACK and rural congregations were examined from the standpoint of rural development on the whole. In addition, the role of ACK congregations in rural development was examined by taking into consideration the fact that ACK congregations were religious communities.

\section{Theoretical Framework}

The study applied the social capital theory as its tool of analysis. Social capital is the sum of the institutions that underpin a society. It is also the glue that holds them together and includes the shared values and rules for social conduct expressed in personal relationship, trust and a common sense of "civic" responsibility that makes society more a collection of individuals. Without a degree of common identification with forms of governance, cultural norms and social values, it is difficult to imagine a functioning society. Researches on the role of social capital in the development process and economic growth are of the view that the market and government cannot always work well. The way in which social capital, whether through local association or other manifestations, performed its role, was centred on three mechanisms: the sharing of information among group members, the reduction of opportunistic behaviour, and the facilitation of collective decision-making (Grootaert et al, 1999). Introduction of new development programmes without deep consideration of local community relationship results in social disintegration and destroys social capital. As the development process has moved from a "top-down" approach to a more "bottom-up" approach, the role of the local community has become more important. Full understanding of community resources, including community relationships and networks, which are widely acknowledged as social capital, is necessary for the developmental planning process. The full use of social community resources promotes the effectiveness of the rural development program.

The most important point in this analysis is the western Christians' attitude towards the African culture - their way of life and religion. This was the African social capital that bonded them very well before Christianity was introduced to Kirinyaga. Before the Anglican CMS opened a mission station at Kabare in Gichugu, Africans lived harmoniously, governed by their own traditional customs, beliefs, cultural norms and social values that enhanced social relations in the society and enabled people to coordinate and achieve common goals. People's willingness to participate in various local community initiatives within their own local institutions was a good indicator of social capital within the African society. However, with the coming of Christianity in Kirinyaga, "alien" beliefs, customs, norms, social values and governance systems were introduced to Africans. This was in contradiction to the African governance system which resulted into conflicts. The form of social capital introduced by Christianity was different from the African cultural norms. In the beginning, the Anglican CMS missionaries regarded their own European civilization as being superior to the African culture and way of life. This ethnocentrism led the CMS missionaries to oppose certain aspects of the African culture as uncivilized, an attitude that has been concomitant with the devaluation and denigration of all things African. It did not matter to the CMS missionaries whether or not these aspects of African culture were forbidden in the Bible (Muga, 1975, p. 100).

The Anglican CMS missionaries considered Africans in Kirinyaga as heathens or pagans who were fundamentally 
evil. As such, the best way to deal with them was initially to destroy all their old, "uncivilized and evil" ways enshrined in their culture, convert them to Christianity through baptism, and purify them by inducting them into the new and better religion and into the 'new' and 'superior' civilization.

\section{Research Findings}

Kirinyaga is occupied by the Gikuyu community who presently occupy the Central region of Kenya. The ancestors of the Kirinyaga community constitute part of the Bantu-speaking groups in Central Kenya, including the Kamba, Embu, Mbeere, Tharaka and Meru people, who share common historical roots that date back to a proto-type population known as the Thagicu speakers who migrated from the north into the Eastern and Southern Africa (Lambert, 1956; Middleton and Kershaw, 1965, p. 14; Muriuki, 1974; Castro, 1995, p. 19; Davison, 1996, p. 29). They settled in the Mount Kenya region between the twelfth and fourteenth centuries (Davison, 1996; Muriuki, 1974; Mwaniki, 2000, p. 16). According to the Kirinyaga community's oral tradition, the Agikuyu originated from their ancestors, Gikuyu and his wife Mumbi. Gikuyu was created by Ngai (God) who then called him to kirimagiaKirinyaga (Mount Kenya), His usual resting place. Gikuyu was shown the beauty of the land at the foot of the mountain called MukurwewaGathanga (in Murang'a County), which Ngai then gave him to occupy with his descendants. The ancestral Thagicu immigrants eventually absorbed or displaced earlier occupants, namely the cattle-keeping Mwoko and Njuwe, and the hunting and gathering Gumba, Athi and Dorobo (Orde-Browne, 1925; Muriuki, 1974; Middleton, and Kershaw, 1972, p. 14). As the Thagicu speakers spread out across southern Mount Kenya, their language differentiated into Ki-Ndia, Ki-Gichugu, Ki-Mathira, Ki-Embu, Ki-Mbeere and related dialects (Spear, 1981; Mutahi, 1983).

\section{The Kirinyaga Social, Economic and Political Institutions on the Eve of Colonial Rule}

The Kirinyaga people's traditional economic, social and political organization was based on belief systems, family kinship and age-group system. The beliefs and practices were all interwoven to give meaning to life (Muraya, 2009; Muriuki, 1974). They also believed in a supernatural creator of life or Supreme Being called NgaimwenyeNyaga (God of Kirinyaga) - the creator of the universe and everything (Muraya, 2009, pp. 44-45; Hobley, 1922; Leakey, 1977; interview with Mr. Easto Njeru Muriuki, 3/3/2010). Kirinyaga people offered sacrifices to their God under a sacred tree known as Mugumo (fig tree) and they also believed in the spirits of the ancestors (Muraya, 2009, p. 45). Kirinyaga practised irua or circumcision as a cultural ritual aimed at instilling these ancestral norms and beliefs into successive generations. Age group, Riika, was one of the most important features in the community's social organization and as a form of African social capital or the glue that held them together. The rite of circumcision (Irua) marked this step for both Kirinyaga men and women. The community also had "generation" sets that were based on a ruling generation that was either referred to as Maina (Irungu) or Mwangi (Muraya, 2009, p. 49). Each generation set ruled for a span of about three decades and the generational names followed one another alternately.

The traditional Kirinyaga political organization was based on three important units. First was the family, Nyumba, which put together all those who were related by blood or marriage. Second was the lineage, Muhiriga that composed of all the descendants of a common grandparent whose leadership was hereditary. Third, was the age grade that included the Kirinyaga male and female who were circumcised together (riikarimwe) and age mates circumcised during the same season and who constituted an age-set (riika) (Gecaga, 2004, p. 67). The three units formed the basis of the Kirinyaga socio-economic and political activities.

Kirinyaga people were mainly agriculturalists. They also kept a considerable number of livestock, chiefly sheep, goats and cattle (Middleton and Kershaw, 1972, p. 18). Kirinyaga people also engaged in both market and long distance trade with the neighbouring communities and with foreigners. Arabs or Waswahili came, though rarely, (Jong, 2000, p. 49) bringing beads, copper and brass wire, clothes and trifles, which they exchanged for elephant ivory and skins. The British colonial forces occupied Kirinyaga through punitive expeditions and imposed their authority by force. From 1896, the colonial government enacted several ordinances aimed at legalizing the Europeans' acquisition of land (KNA, D.C/KBU/3/8, 1890-1916). These orders gave the protectorate government jurisdiction over all lands previously occupied by Africans. All Kirinyaga community became tenants of the government (Sandgren, (1989, p. 33).

Kirinyaga community's willingness to participate in various local community initiatives within their own local institutions was a good indicator of social capital. However, colonial establishment in Kirinyaga, alien customs, norms, social values and governance systems were introduced to Africans. This was in contradiction to the African governance system. The change in the Kirinyaga traditional land ownership meant that the traditional cultural practices could only be pursued within particular squatter land and reserve boundaries as opposed to their traditional set up (Basil, 1968, pp. 241-256). It also meant that the 'divine' traditional right of every Kirinyaga 
circumcised man to a piece of land was not a guarantee with the settler's invasion (KNA, D/C/KBU/1/1, 19071908). Thus, with the continuous shortage of land for food production, Kirinyaga people found it difficult to continue with the normal cultural celebrations. The scarcity of land also meant that the traditional division of labour would be altered significantly. The erosion of traditional authority, including the generation-sets, diminished the cultural significance of the sacred groves. The colonial government regarded customary political organization as too diffuse for administrative purposes (Dundas, 1915; Muriuki, 1974). It quickly initiated its own local hierarchy of appointed chiefs, headmen and other functionaries, supervised by white officials.

\section{The Planting of ACK in Kirinyaga}

The missionary occupation in Kirinyaga coincided with that of the European settlers. Mission stations were established across the Kenyan highlands between 1900 and 1910. In 1910, two new CMS stations were started, in the territory of the Gichugu people, at Kabare and Embu, a hundred miles north of Nairobi. Kabare mission (Gichugu division) was established in 1910 by Rev. Canon A. W. Crawford (interview with the late ACK Archbishop Rt. Rev. Dr. David Gitari, 7/11/2009; interview with Mr. J.M. Nyagah, 9 $9^{\text {th }} 11 / 2009$; interview with ACK church Elders3 $3^{\text {rd }} / 9 / 2010$; interview with Ben Knighton 6 6 th/8/2010; FGD interview with Bernard Kababi, Joseph Mwai and Jotham Nguri (Cannon) 17/4/2010; KNA:MSS/61/639; KNA:PC/CP/1/5/1; Crawford, 1913), while Mutira mission (Ndia division) was established by Rev. Laight (ACK Diocese of Kirinyaga, 2012; Cole, 1970). Missionaries encouraged people to adopt a package of Western culture (Castro, 1995, p. 116). The Anglican CMS missionaries' activities had various related aims beyond the overriding aim of preaching the Gospel. These included impacting both the physical and spiritual needs of their faithful. CMS missionaries also engaged in educational and development work, which cumulatively sought to bring about a cultural shift in Kirinyaga (A.I.P.C.A; Mwaniki, 2000, p. 53). Therefore, along with the Word of God, they sometimes fed and clothed the hungry and established health centres (Mwaniki, 2000). Many Kirinyaga people quickly joined these missions, and a section of them went along with the changing of their traditions and culture. They valued school education as a means for individual advancement in the colonial society. This is authenticated by many of those who were educated at the CMS-Kabare school, and who secured jobs as teachers and government clerks, at the time regarded as well-paying jobs (Sluiter, 1956).

The Anglican CMS established Christian communities that were viewed as centres for transforming the first African converts in Kirinyaga. The new converts were separated from their local community members and lived in the Christian communities where they would be taught new skills and introduced to Western culture. In addition, the new African converts were taught literacy skills, trained in modern medicine, introduced to new crops and modern agricultural skills. Similarly, the African converts were taught modern artisan skills and lawful commerce. Eventually, many of the early converts left the Christian communities to start their own churches in the nearby communities where they came from. Although their spiritual message sometimes met resistance, services such as schooling and public healthcare provided by the CMS soon developed a receptive following (Kalu, 2007; Crawford, 1913; Cagnolo, 1933 (first edn); Castro, 1995, pp. 115-116). People quickly valued schooling as a means for individual advancement in colonial society.

The pace, extent and direction of cultural change that generated an undercurrent of tension between the Kirinyaga society and the missionaries, occasionally erupted into crisis, most dramatically in the circumcision controversy, which clearly illustrated the dual sources of cultural conflict within the mission; for while it represented primarily a 'protest of conservation' aimed at defending a vital feature of traditional life, there were also elements of a 'protest of transformation' aimed at enhancing Kirinyaga society's ability to cope with the modern world through the provision of enhanced education (Strayer, 1978, p. 157). The WWI played its role in disrupting the balance of the Kirinyaga society traditional institutions. Henceforth, the Kirinyaga society experienced a considerable political awakening that revolutionised existing traditional values and customs.

\section{The ACK in Kirinyaga in the Post WWII Years, 1945-1963}

The Second World War was a momentous point in the history of Kirinyaga Christianity. It ignited the decolonization process that reverberated across the religious landscape. The ACK in Kirinyaga was not spared. By the time World War Two broke out, the ACK was well versed with Kirinyaga people after two decades of working experience. There was less social turbulence during the war because there was no local crisis (Nyaundi, 1993, p. 129). Secondly, by that time ACK was considerably established and pastoral duties were increasingly transferred over into African hands. By 1955, Kenya's premier Bishops Rev. Festo Olang' and the Rev. Obadiah Kariuki were auspiciously ordained (Caples, 2011, p. 16). Thirdly, as the colonial government was recruiting men for war service, the ACK mission converts in Kirinyaga were not conscripted. Fourthly, the ACK's eschatological view of Christ's imminent return must have suffered poor exegesis/eisegesis during the war because the Bible mentions "wars and rumours 
of wars" as an indicator of that imminence. Kershaw (1997) observes that the Second World War veterans were a disenfranchised lot in Kirinyaga. They had come mainly from the poverty stricken squatters, most of whom had some schooling, but the military had provided more education and technical training. They had high hopes that the reparation pay and savings would allow them to open businesses in Kirinyaga, but the administration and chiefs denied them the necessary permits (Kershaw, 1997). According to the administration, the area was already saturated with small businesses and therefore there was no need to issue fresh licenses. Few would be able to comply immediately with all the existing regulations, even if they were successful in their applications.

Towards the late 1940s, there was increasing hatred against Europeans. ACK missions did not escape the violence in which these feelings were manifest. The main reason lay in the Kenyan perceived lack of differentiating between missionaries and the settlers in matters of land ownership, which was the biggest alienating factor (Githige, 1982, p. 116). This led to the origin of native protest movement known as Mau Mau. In Kirinyaga, oath taking as a first step in recruiting Mau Mau fighters was indeed the order of the day (Gathogo, 2014, p. 21). According to General Matene (1922) (real name was NyamuwaMuriakori) (Gathogo, 2014), who was among the first Mau Mau oath administrators in Kirinyaga, most of the initiates brought to him for compulsory oath taking included Christians, teachers, peasant-farmers, local sub-chiefs and people of all walks of life. In Kirinyaga, as in the rest of Mount Kenya region, Home Guards, who were mainly Anglican Christians, would move swiftly to burn the house of a person who had taken the Mau Mau oath. During the State of Emergency, Christians in Kirinyaga were mistaken to have been colonial loyalists. The ACK's concern was with the rehabilitation of the Mau Mau detainees as well as the activities of the security forces. The late Archbishop Kuria, as a young man, ministered to the detainees for three years as a special chaplain (CPK, 1994, p. 88). The Anglican Church took a big step in Africanization by consecrating two Kenyan bishops - Rev. Festo Olang' and Rev. Obadiah Kariuki in 1955 (Caples, 2011, pp. 132133).

During the early 1960s, the ACK in Kirinyaga proved to be one of the first institutions to recognize that the colonial administration was drawing to an end and thus, the need to develop Kirinyaga people to assume leadership responsibilities. The pressure towards independence was increasing. African leadership had grown more rapidly within the ACK than it had within the State (CPK, 1994, p. 89).

\section{The ACK in Kirinyaga in Post-independent Kenya to the Promulgation of the Kenya's 'New' Constitution, 1963 - 2010}

After independence in 1963, those who assumed political leadership were mainly beneficiaries of mission schools. However, the period from 1963 to 2010 was characterized by the implosion of the state, the attack on the dominant role of the church in the public space and the churches' various strategies for survival. The church lost control of schools, hospitals and other charitable institutions. By 1980s, most economies had started collapsing; poverty enveloped communities; abuse of human rights and legitimacy crises followed apace. Therefore, the question could be asked: What was the role of the ACK during that era in Kenya? A strange thing happened: the ACK together with other mainline churches had been accused of colluding with the colonial masters during the colonial period, and for being silent during the predatory Mau Mau uprising; but suddenly their relevance in the public space was recognized. The leaders were the only ones who could be trusted to chair or broker the democratic experiments. Before the referendum which took place on $4^{\text {th }}$ August 2010, the late ACK Archbishop Rt. Rev Dr. David Gitari was involved in Civic Education with regard to the proposed Constitution published by the Attorney General on $6^{\text {th }}$ May 2010 at the Philadelphia Retreat and Conference Centre in Kirinyaga (The Philadelphia Declaration, 2011, p. 1). The Centre organized eight seminars during the month of July, 2010 which were attended by an average of 250 people per day. Therefore, Philadelphia Centre contributed towards the acceptability of the proposed Constitution by majority of Kirinyaga voters. When the new Constitution was promulgated by the president on $27^{\text {th }}$ August 2010, Philadelphia Centre felt duty bound to organize seminars on the implementation of the new Constitution.

\section{Christian Community Services of Mt. Kenya East (CCSMKE)}

Following what is referred to as the "regionalization process within CCSMKE", the dioceses were grouped into clusters or regions for the purposes of facilitating development work. The CCSMKE is the development arm of the four ACK dioceses of the former Mt. Kenya East Diocese that currently comprises the ACK diocese of Embu, Kirinyaga, Meru and Mbeere. Mt. Kenya East Region is the area covered by Mt. Kenya East Diocese and now comprises Kirinyaga, Meru, Embu, Mbeere, and Marsabit Dioceses. Mt Kenya East Diocese was created in 1976 with the late ACK Archbishop Rt. Rev. Dr. David Gitari as its first Bishop. In 1977, Bishop Gitari pioneered development efforts, which saw the schools' programme take off in 1978. The history of CCSMKE programmatic work can be traced to the beginning of the health programme, funded by EZE. From that beginning, CCS was involved in evolutionary innovative health programmes based on the World Health Organization's (WHO) 
recommendation of primary health care and on the goodwill, resources and capacity of the ACK.The health programme expanded in the course of the years to incorporate the opening of clinics and dispensaries among others. As the health programme took root in CCSMKE, a programme related to food increase emerged.

Rt. Rev Dr. David Gitari was actually disturbed by the perpetually recurring famines and the fact that donor partners responded promptly to famine emergencies, but were unable to provide a permanent solution to the perpetual food problem (personal interview with the late Rev. Gitari, 28/2/2008; TAABCO, 2008; CCSMKE, 2005). He was therefore convinced that a lasting solution to the food problem was the best way forward. CCSMKE sequentially implemented the food security initiative through donor support and collaboration with partners and the public sector. The health facilities (clinics and laboratories) have been performing extremely well and are the lead enterprises in the project. They have been acting as referral centres from the mobile clinics and are lauded for bringing health closer to the people. The hostel facilities are used as retreat and conference centres by the communities and beyond. Because of their location and good services, the hostels have been providing facilities that can be found away from the well-known retreat centres in the city.

Other enterprises such as agro-vet and farm produce stores, livestock units and farms have had a significant impact in the community. The stores are used as farm input supply stations where farmers are sold farm supplies at affordable prices. This has enhanced the cost and mobility factor, especially in areas like Macumo and Mitunguu. The livestock units and farms are used as training centres, and at the periphery as income generating activities. In their capacity as training centres, the farms have helped the communities adopt new technologies. The CCSMKE Boards of Directors and staff have been coordinating and managing development with partners and stakeholders.

Over the period of 30 years since the birth of Mt. Kenya East region (1980-2010), the team had made many tangible achievements (CCSMKE, 2005, p. ii). First major achievement is change of community attitude towards development and enhancement of self-sustainability and independence of thought. They have also enhanced collaboration with the government of Kenya $(\mathrm{GoK})$ among other players. The organization is also represented in the district development committee and other public committees. The second achievement is leading the church to self-reliance and sustainability by deliberately developing the capacity of resource mobilization and fund development. The third achievement is improvement in community leadership by recruiting and involving community leadership in what they do while the same leadership plays a part in the same community. The fourth achievement is the enhancement of skills in resource mobilization at the community level by training community resource persons, project committees and their leaders that has led to well managed community programmes. The fifth achievement is the reduction in poverty level after adopting improved food production and animal husbandry techniques that have improved their lifestyles. This is evidently confirmed by the low poverty index in areas such as Kirinyaga, Embu and Meru, which are served by the CCSMKE. The sixth achievement is the contribution made in the mitigation against HIV and AIDS through the usage of church structures to reduce the prevalence of HIV and AIDS in the region. The seventh achievement is the improvement in farming technologies and spearheading the discovery of new technologies such as organic farming and maximizing small land resources, e.g. portable gardens. The eighth is the increased appreciation of the work done by the church, the board and the community in the region from monitoring and evaluation committees. The ninth achievement is contribution to disaster mitigation and preparedness during an emergency by working with everyone in the community. The tenth achievement is modelling other regions and partners to replicate their model. The eleventh achievement is creation of employment opportunities for the youth from all the enterprises in the sustainability projects. The twelfth achievement is building capacity in all areas of development among the targeted groups mostly through field days. The project and station development committees are continually trained in order to build and sustain their capacity to refine their approach by receiving positive feedback from the beneficiaries of the programmes. The final achievement is through the staff growth and development for individual sustainability (CCSMKE 2005).

\section{Conclusion}

The social gospel of the ACK in Kirinyaga worked wonders by transforming Kirinyaga people in various aspects of life. The Kirinyaga gave up their skin wear for fabric cloth and left compound bonfires (miakiya boo-ini) for the church, schools and hospitals. Additionally, they started growing cash crops such as tea, coffee and bananas. The plains, originally used, for communal grazing where wild and domestic animals mingled naturally and freely were developed into rice paddles. They gave up traditional dances and sang hymns and canticles churned out by choirs clad in butterfly colours. The most remarkable change was the embracing of the new religion, Christianity, and all ensembles (ACK Diocese of Kirinyaga, 2012, pp. 118-119). The ACK Kirinyaga sponsored academic institutions as follows: 53 secondary schools; 54 primary schools and 9 youth polytechnics. In addition, the church embarked 
on financially empowering members of the community through micro-financing. Similarly, the ACK's CCSMKE was involved in evolutionary health programme based on World Health Organisation (WHO) recommendation of primary health care and relying on the goodwill, resources and capacity of the ACK in Kirinyaga (CCSMKE, 2005,p. 10). The ACK's involvement in community health resulted in the establishment of community health centres in CCSMKE stations at Wang'uru, Mayori, Machumo, Mitunguu, Maua, Marsabit and Isiolo. From a community that was plagued by ignorance, superstitions, uncertainties, poverty and diseases, Kirinyaga produced renowned professors, doctors, lawyers, judges, administrators, senior political and Ecclesiastical leaders, engineers, historians and scholars of all shades (Gathogo, 2011, p. 174). However, the ACK leadership in Kirinyaga was faced with modern challenges. Quite a number of the adherents in the youth bracket were held captive by drug abuse especially alcoholism; the family institution was shaken to the base; separation and rising cases of divorce threatened to overtake registration of new weddings and Street families became an acceptable social phenomenon (ACK Diocese of Kirinyaga, 2012).

In conclusion, the Anglican Church in Kirinyaga and other churches need to embrace the above emerging issues, lessons and factors as a basis for involvement in social gospel. The ACK in Kirinyaga has a unique place in the community. It is the only institution that brings together millions of Kirinyaga people every week without seeking a license from the Kenya government. That means the Anglican Church in Kirinyaga has great potential as the promoter of the social gospel. To have a captive audience every Sunday is an opportunity that other institutions envy. The Anglican Church in Kirinyaga needs to enhance its role in social gospel. This is a fundamental task if the Anglican Church in Kirinyaga is to be truly African in its social work and if it is to serve the poor masses in Kirinyaga. The Anglican Church in Kirinyaga is called to be courageous and prophetic in demanding for social justice.

\section{References}

Archival Sources

KNA,D.C/KBU/3/8, 1890-1916

KNA, D/C/KBU/1/1, 1907-1908

KNA: MSS/61/639

KNA: PC/CP/1/5/1

\section{Government of Kenya or Republic of Kenya Publications}

GoK: (2002). Kirinyaga District Development Plan, 2002-2008. Nairobi: Government Printer.

GoK; (2008). Kirinyaga District Development Plan, 2008-2012. Nairobi: Government Printer.

\section{List of Oral Interviews}

The late ACK Archbishop Rt. Dr. David Gitari, 71 years, first interviewed on 28/02/ 2008 and second interviewed on November $7^{\text {th }}, 2009$, at his Philadelphia home in Ngiriambu, Kirinyaga.

Mr. James MunyambuNyagah, 56 years, interviewed on 09/11/2009

Mr. Erasto Njeru Muriuki, 72 years interviewed on 03/03/2010

Mr. JothamNguri (Cannon), 87 years interviewed on 17/04/2010

Mr. Alfred Ireri, 72 years interviewed on $27 / 08 / 2010$

Mr. Arthur Karembu, 93 years interviewed on 27/08/2010

Mr. Bernard MakangaMatu, 93 years interviewed on 27/08/2010

Mr. Walter Njiru, 85 years interviewed on 27/08/2010

Mr. DancunNjimia, 90years interviewed on 19/05/2010

Mr. Ben Knighton, 55 years interviewed on 16/08/2010

Mr. ElephasGacokiNjera, 77 years interviewed on 03/09/2010

Mr. Bernard Kababi, 92 years interviewed on 17/04/2010

Mr. RufueMuriithi, 110 years interviewed on 23/04/2010

\section{Unpublished Thesis, Seminar and Conference Papers}

Mwaniki, L. M. (2000). "The Impact of The Church on The Development of The Identity of An African Christian Woman: A Case Study of the Anglican Church of Kenya, Diocese of Kirinyaga 19101999”, Master of Theology in African Christianity at the University of Natal Pietermaritzburg. 
Muraya, M. W. (2009). "Colonial Transformation of Female Circumcision and Its Impact on Women's Roles and Gender Relations Amomg the Agikuyu of Kiambu From 1895 To 1963”, M.A. Thesis at Kenyatta University.

\section{Books}

ACK Diocese of Kirinyaga (2012). Holistic Church Growth: 100 years of Mutira Mission). Kerugoya: ACK Diocese of Kirinyaga.

ACK (2000). Ministry of Abundant Life: How The Anglican Church of Kenya is Reaching

Out To The Poor Communities Through Christian Community Services Nairobi: Anglican Church of Kenya.

ACK Diocese of Embu (2010). Ten Great Decades of Faith (1910 - 2010). Embu: ACK

Diocese of Embu.

Barrett, D.A. (1971) (ed.). "African Initiatives in Religion" in 21 Studies from Eastern and Central Africa. Nairobi: East African Publishing House.

Basil, D. (1968). African in History: Themes and Outline. London: Heinemann.

Cagnolo, Fr. C. (1933). The Akikuyu. Nyeri: Catholic Mission of Consolata Fathers.

Caples, C.B. (2011). History of the Anglican Church in Kenya (Anglican Studies 1). Maseno: St. Philip's Theological College.

Castro, A.P. (1995). Facing Kirinyaga: A Social History of Forest Commons in Southern Mount Kenya. London: Intermediate Technology Publication Ltd.

CCSMKE (2003). Report on Round Mount Kenya In Christ's Footsteps: Evaluation of the Integrated Programme on Poverty Alleviation Phase II. Kerugoya, CCSMKE.

CCSMKE (2005). 25 Great Years of Reaching Out. Kerugoya: A Christian Community Services of Mt. Kenya East Publication.

CPK (1994). Rabai to Mumias. Nairobi: Uzima Press.

Crawford, E.M. (1913). By The Equator's Snowy Peak: A Record of Medical Missionary Work And Travel in British East Africa. London: CMS.

Davison J. (1996). Voices from Mutira: Change in the Lives of Rural Gikuyu Women, 1910-1995. Colorado: Lynne Rienner Publisher, Inc; London: Lynne Rienner Publisher, Inc.

Debrunner, H. (1967). A History of Christianity in Ghana. Accra: Waterville Publishing House.

Gathogo, J. (2011a). The Pangs of Birth in African Christianity: Essays in Commemoration of One Hundred Years of Mutira Anglican Mission (1912-2012). Saarbrucken: LAP LAMBERT Academic Publishing GmbH \& Co. KG.

(2011b). Mutira Mission: An African Church Comes of Age in Kirinyaga, Kenya (1912-2012). Limuru: Zapf Chancery Publishers Africa Ltd, C/O St. Paul's University.

Gecaga, M. G. (2004). "Issues in the Controversy Surrounding the Introduction of Family Life Education in Kenya Schools 1987-1997”. Ph.D. Thesis, Kenyatta University. 
Groenewegen, T. and Githige, R. (1987). Christian Religious Education Book 2. Nairobi: Longman.

Grootaert, Christian, Gi-Taik Oh and Anand Swamy (1999). The Local Level Institutions Study: Social Capital and Development Outcomes in Burkina Faso. Local Level Institutions Working Paper No. 7. Washington: The World Bank.

Hastings, A. (1991). A History of English Christianity 1920-1990. London: SCM Press Ltd.

Hobley, C. W. (1922). Bantu Beliefs and Magic with Particular Reference to the Kikuyu and Kamba Tribe of Kenya Colony: Together with some reflections on East Africa after the war. Nairobi: Kenya Literature Bureau.

Kalu, O.U. (2007). African Christianity: An African Story. Trenton; Asmara: Africa World Press.

Kershaw, G. (1997). Mau Mau from Below. Oxford: James Currey; Nairobi: E.A.E.P.; $\quad$ Athens: Ohio

University Press.

Lambert, H. E. (1956). Kikuyu Social and Political Institutions. London: Oxford University Press.

Leakey, L. S. B. (1977). The Southern Kikuyu Before 1903, Vol. II \& III. London: Academic Press.

Lonsdale, J. M. (2002). "Mission Christianity \& Settler Colonialism in Eastern Africa" in Hansen, H.B. \& M. Twaddle Christian Missionaries \& State in the Third World. Oxford: James Currey.

Middlton, J. and G. Kershaw (1965). The Kikuyu and Kamba. London: International African Institute.

Muga, E. (1975). African Response to Western Christian Religion: A Social Analysis of African Seperist Religious and Political Movements in East Africa. Nairobi: East African Literature Bureau.

Muriuki, G. (1974). A History of the Kikuyu, 1500-1900. Nairobi: Oxford University Press.

Mutahi, E. (1983). Sound Change and the Classification of the Dialects of South Mount Kenya. Berlin: Reimer.

Nyaundi, M. Nehemiah (1993). Religion and Sociological Change: A Sociological Study of Seventh-day Adventism in Kenya. Lund: Lund University Press.

Orde-Browne, G. St. J. (1925). The Vanishing tribes of Kenya. London: Seeley, Service and Co.

Sandgren, D. (1989). Christianity and the Kikuyu. Religious Divisions and Social Conflict.

New York: Peter Lang Publishing.

Sluiter (Kershaw), G. (1956). A Study of Kabare Village in Embu District. Nairobi: Christian Council of Kenya.

Spear, T. (1981). Kenya’s Past. London: Longman.

Strayer, R. W. (1978). The Making of Mission Communities in East Africa: Anglicans and

Africans in Colonial Kenya, 1875-1935. Nairobi: Heinemann.

TAABCO (2008). The Church in Development - A Report on the Social Ministry of the

Anglican Church of 
Kenya, 30 years on. Nairobi.

The Philadelphia Declaration Report, 2011. Kirinyaga.

Wilson, M. (1969). "Co-operation and Conflict: The Eastern Cape Frontier". In Monica Wilson and Leonard Thompson, eds., South Africa to 1870, vol. 1 of The Oxford History of South Africa series. Oxford: Clarendon Press.

\section{Journals}

Dundas, C. (1915). The Organization and Laws of Some Bantu Tribes in East Africa. Journal of the Royal Anthropological Society 45: 234-306.

Gathogo, J. (2014). "Mau Mau War and the Church in Kirinyaga, Kenya: Accounting for the tension and conflict (1952-1960)" StudiaHistoriaeEcclesiasticae, December 2014, 40

(2), 19-41.

\section{Internet sources}

County Council of Kirinyaga Website. Retrieved 16 August 2012.

\section{About the Authors:}

Enock Akattu and Edwin Atianyi Gimode are faculty, Department of History, Archaeology and Political Studies while until her demise in eary 2020, Mildred Ndeda was faculty, Department of History, Religion and Philosophy, Jaramogi Oginga Odinga University of Science and Technology.

Email contact: akattu.enock@ku.ac.ke 